\title{
Antivirális és gyulladásellenes kezelési lehetőségek COVID-19-ben
}

\author{
Szekanecz Zoltán dr. ${ }^{1}$ - Bogos Krisztina dr. ${ }^{2}$ \\ Constantin Tamás dr. ${ }^{3}$ - Fülesdi Béla dr. ${ }^{4}$ - Müller Veronika dr. ${ }^{5}$ \\ Rákóczi Éva dr. ${ }^{1}$. Várkonyi István dr. ${ }^{6}$ - Vályi-Nagy István dr. ${ }^{7}$ \\ ${ }^{1}$ Debreceni Egyetem, Általános Orvostudományi Kar, Belgyógyászati Klinika, Reumatológia, Debrecen \\ ${ }^{2}$ Országos Korányi Pulmonológiai Intézet, Budapest \\ ${ }^{3}$ Semmelweis Egyetem, Általános Orvostudományi Kar, II. Gyermekgyógyászati Klinika, Budapest \\ ${ }^{4}$ Debreceni Egyetem, Általános Orvostudományi Kar, Aneszteziológiai és Intenzív Terápiás Klinika, Debrecen \\ ${ }^{5}$ Semmelweis Egyetem, Általános Orvostudományi Kar, Pulmonológiai Klinika, Budapest \\ ${ }^{6}$ Debreceni Egyetem, Általános Orvostudományi Kar, Infektológiai Klinika, Debrecen \\ ${ }^{7}$ Dél-pesti Centrumkórház, Országos Hematológiai és Infektológiai Intézet, Budapest
}

Az új típusú koronavírus-fertőzés (COVID-19) nagy terhet ró az egészségügyi ellátórendszerre és a társadalomra. A betegségnek három nagy szakasza van, melyek alapvetően meghatározzák a kezelést. Az I-IIA fázisban az antivirális, míg a IIB-III. fázisban a gyulladásgátló kezelés áll előtérben, melyhez intenzív terápiás, szupportív kezelés csatlakozik. A jelen ajánlás kizárólag a gyógyszeres kezelésre vonatkozik, és a rendelkezésre álló bizonyítékok alapján foglalja össze a terápiás lehetőségeket. Emellett egy javasolt kezelési algoritmust is tartalmaz.

Orv Hetil. 2021; 162(17): 643-651.

Kulcsszavak: új típusú koronavírus-fertőzés (COVID-19), koronavírus, citokinvihar, antivirális kezelés, citokingátló kezelés, kortikoszteroid, interleukin-6-gátlás, Janus-kináz-gátlás, intravénás immunglobulin

\section{Antiviral and anti-inflammatory therapies in COVID-19}

\begin{abstract}
The novel coronavirus infection (COVID-19) places a heavy burden on the health care system and our society. There are three major stages in the disease that fundamentally determine treatment approaches. Phases I-IIA require primarily antiviral treatment. In phases IIB-III, anti-inflammatory treatment is needed accompanied by intensive and supportive care. This recommendation applies only to pharmacotherapy and summarizes the therapeutic options based on the available evidence. It also includes a proposed treatment algorithm.
\end{abstract}

Keywords: novel coronavirus infection (COVID-19), coronavirus, cytokine storm, antiviral treatment, cytokine inhibition treatment, corticosteroid, interleukin-6 inhibition, Janus kinase inhibition, intravenous immunoglobulin

Szekanecz Z, Bogos K, Constantin T, Fülesdi B, Müller V, Rákóczi É, Várkonyi I, Vályi-Nagy I. [Antiviral and antiinflammatory therapies in COVID-19]. Orv Hetil. 2021; 162(17): 643-651.

(Beérkezett: 2021. február 26.; elfogadva: 2021. március 22.)

\section{Rövidítések}

ARDS = (acute respiratory distress syndrome) akut légzési distressz szindróma; $\mathrm{BCG}=$ Bacillus Calmette-Guérin; COVID-19 = (coronavirus disease 2019) koronavírus-betegség 2019; CRP = C-reaktív protein; cTn = cardialis troponin; EUA $=$ (emergency use authorization) sürgősségi használati engedélyeztetés; EULAR = (European League Against Rheumatism) Európai Reumatológiai Társaság; FDA = (U.S. Food and Drug Administration) az Amerikai Egyesült Államok Élelmiszer-biztonsági és Gyógyszerészeti Hivatala; $\mathrm{FiO}_{2}=$ (fraction of inspired oxygen) a belégzett oxigén koncentrációja; GGO = (ground-glass opacity) tejüvegszerü homály; GOT = glutamátoxálacetát-transzamináz; hIVIG = humán intravénás immunglobulin; IL = interleukin; ILIRa = interleukin-1-receptor-antagonista; ITO = intenzív terápiás osztály; JAK = Janus-kináz; LDH = laktátdehidrogenáz; LMWH = (low-molecular-weight 
heparin) kis molekulatömegü heparin; MERS = (Middle East respiratory syndrome) közel-keleti légzési szindróma; MIS = (multisystem inflammatory syndrome) multiszisztémás inflammatorikus szindróma; $\mathrm{MOF}=($ multiorgan failure $)$ sokszervi elégtelenség; NT-proBNP = N-terminális pro-B-típusú natriureticus peptid $\mathrm{PaO}_{2}=$ parciális oxigénnyomás; $\mathrm{PCR}=($ polymerase chain reaction) polimeráz-láncreakció; $\mathrm{PCT}=$ prokalcitonin; SARS-CoV-2 = (severe acute respiratory syndrome coronavirus 2) súlyos akut légúti tünetegyüttest okozó koronavírus-2; WHO = (World Health Organization) Egészségügyi Világszervezet

Az új típusú koronavírus (SARS-CoV-2) által okozott COVID-19 több szakaszra osztható, amelyek meghatározzák a klinikai lefolyást, a diagnosztikus teendóket és az alkalmazott terápiát is (1.ábra) $[1,2]$.

A jelen terápiás ajánlás a klinikai stádiumbeosztáshoz igazítja a COVID-19-betegek ellátását, figyelembe véve a legfrissebb terápiás kézikönyvet is [3]. Az összefoglaló kizárólag a gyógyszeres kezelésre, ezen belül az antivirális és gyulladásgátló szerekre koncentrál. Részletesen nem tárgyaljuk az antibakteriális szereket és az antikoagulánsokat. Az ajánlás nem érinti a szupportív és nem farmakológiai eljárásokat (például testhelyzet-változtatás, oxigénterápia, nem invazív és invazív lélegeztetési módok, mesterséges táplálás), a palliatív ellátást, a rehabilitációt, a vakcinációt (mint megelőzést), valamint a járványügyi intézkedéseket és megfontolásokat. Az anyag rövid és tömör összefoglalót tartalmaz, hiszen részletes terápiás kézikönyv [3] és WHO klinikai ajánlás [4] rendelkezésre áll.

Ez az ajánlás az általános elveket tükrözi, melyekhez a helyi adottságoknak és a gyógyszerekhez való hozzáférésnek a lehetőségeit igazítani kell. Ám mindenképpen fontos, hogy a COVID-19-beteget kezelő összes centrum hozzájuthasson e terápiás lehetóségekhez. Megjegyezzük, hogy az ajánlás a 2021. február-márciusi állapotot tükrözi, a közlemények és evidenciák napról napra változnak.

\section{A COVID-19 stádiumai és jellemzői}

A COVID-19 lefolyását időben három stádiumra osztják. Az I. szakasz a korai fertőzés időszaka lázzal, légúti vagy gastrointestinalis tünetekkel, lymphopeniával. A II. szakasz a pulmonalis fázis. Ezt két alszakaszra osztják: a IIA a nem hypoxiás, míg a IIB a hypoxiás fázis. Végül, a III. fázis a multiszisztémás gyulladás (MIS) szakasza, amelynek hátterében az ún. citokinvihar áll, de az ún. endothelitis, a coagulopathia is szerepet játszik a kialakuló sokszervi károsodásban (1. ábra; 1. táblázat) $[1,2,5]$. A diagnosztika alapjai: a klinikum, a vírusdiagnosztika (PCR, antigén), a képalkotók és a laboratóriumi biomarkerek (1. táblázat) [1, 2, 5-7]. A biomarkerek külö-

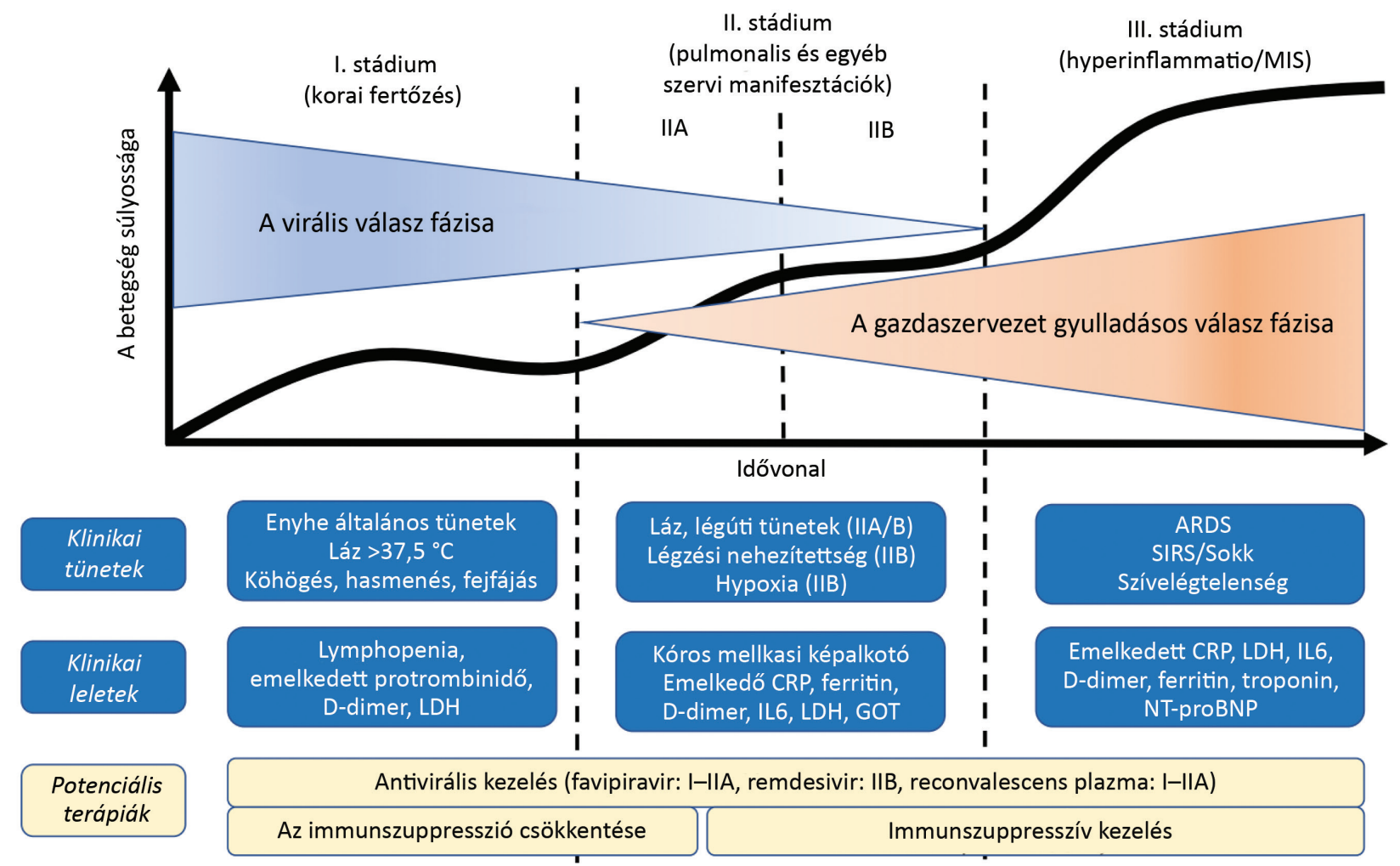

1. ábra

A COVID-19 szakaszai, klinikuma és általános kezelési elvei [1, 2]

ARDS = akut légzési distressz szindróma; COVID-19 = koronavírus-betegség 2019; CRP = C-reaktív protein; GOT = glutamát-oxálacetát-transzamináz; IL6 = interleukin-6; LDH = laktátdehidrogenáz; MIS = multiszisztémás inflammatorikus szindróma; NT-proBNP = N-terminális pro-Btípusú natriureticus peptid; SIRS = szisztémás immunválasz szindróma 
1. táblázat |A COVID-19 fázisai, felismerése és terápiás alapelvei $[1,2,5-7]$

\begin{tabular}{|c|c|c|c|}
\hline Fázis & Jellemzők & Diagnosztika & Terápiás alapelvek \\
\hline $\begin{array}{l}\text { I. } \\
\text { A korai fertőzés } \\
\text { fázisa }\end{array}$ & $\begin{array}{l}\text { - Vírusinokuláció + } \\
\text { korai fertőzés }\end{array}$ & $\begin{array}{l}\text { - Klinikai: tünetmentes vagy hőemelkedés } \\
\left(<37,5{ }^{\circ} \mathrm{C}\right) \text {, gyengeség, köhögés, hasmenés, } \\
\text { anosmia, ageusia, conjunctivitis } \\
\text { - Vírus: SARS-CoV-2-PCR/antigénteszt } \\
\text { - CT: negatív vagy lokalizált subpleuralis GGO } \\
\text { - Labor: enyhe lymphopenia, normálvérgáz és egyéb } \\
\text { laborok }\end{array}$ & $\begin{array}{l}\text { - Otthoni kezelés } \\
\text { - Kis dózisú ASA } \\
\text { - Antivirális (favipiravir, szelektált esetekben } \\
\text { bamlanivimab) } \\
\text { - Reconvalescens plazma (szelektált esetekben) } \\
\text { - Korábbi immunszuppresszió csökkentése/ } \\
\text { leállítása (az alapbetegség szerint) }\end{array}$ \\
\hline $\begin{array}{l}\text { IIA } \\
\text { Pulmonalis fázis } \\
\text { hypoxia nélkül }\end{array}$ & $\begin{array}{l}\text { - Tüdőérintettség } \\
\text { hypoxia nélkül }\end{array}$ & $\begin{array}{l}\text { - Klinikai: láz }\left(>37,5^{\circ} \mathrm{C}\right) \text {, köhögés, hasmenés, } \\
\text { fejfájás, arthralgia, myalgia } \\
\text { - CT: GGO, reticulatio, szervülő pneumonia } \\
\text { - Vérgáz: } \mathrm{SaO}_{2} \geq 92 \% ; \mathrm{PaO}_{2} / \mathrm{FiO}_{2} \geq 300 \mathrm{Hgmm} \\
\text { - Labor: lymphopenia } \uparrow \text {, enyhe LDH } \uparrow, \text { PCT, CRP, } \\
\text { ferritin és D-dimer mérs. } \uparrow\end{array}$ & $\begin{array}{l}\text { - Otthoni/kórbázi kezelés } \\
\text { - Antivirális (favipiravir vagy remdesivir, } \\
\text { szelektált esetekben bamlanivimab) } \\
\text { - LMWH-profilaxis } \\
\text { - Reconvalescens plazma (szelektált esetekben) } \\
\text { - Korábbi immunszuppresszió csökkentése/ } \\
\text { leállítása (az alapbetegség szerint) (A), kis } \\
\text { dózisú kortikoszteroid megfontolandó (B) }\end{array}$ \\
\hline $\begin{array}{l}\text { IIB } \\
\text { Pulmonalis fázis } \\
\text { hypoxiával }\end{array}$ & $\begin{array}{l}\text { - Tüdőérintettség } \\
\text { hypoxiával }\end{array}$ & $\begin{array}{l}\text { - Klinikai: láz }\left(>37,5{ }^{\circ} \mathrm{C}\right) \text {, légzési nehezítettség, } \\
\text { hypoxia, arrhythmia } \\
\text { - CT: GGO, reticulatio, szervülő pneumonia } \\
\text { („crazy paving”) } \\
\text { - Vérgáz: } \mathrm{SaO}_{2}<92 \%, \mathrm{PaO}_{2} / \mathrm{FiO}_{2}<300 \mathrm{Hgmm} \\
\text { - Labor: lymphopenia } \uparrow \text {, thrombocytopenia, GOT } \uparrow \\
\text { (transaminitis), } \mathrm{LDH} \uparrow, \mathrm{CRP} \text {, ferritin, IL6 és } \\
\text { D-dimer tovább } \uparrow, \mathrm{cTn} \text { és NT-proBNP mérs. } \uparrow\end{array}$ & $\begin{array}{l}\text { - Kórbázi kezelés } \\
\text { - Antivirális (remdesivir, szelektált esetekben } \\
\text { bamlanivimab) } \\
\text { - Convalescens plazma (szelektált esetekben) } \\
\text { - Kis dózisú ASA megfontolandó } \\
\text { - LMWH-profilaxis } \\
\text { - Kortikoszteroid (1. dexametazon, 2. metil- } \\
\text { prednizolon) a tüdőérintettségtől függően }\end{array}$ \\
\hline $\begin{array}{l}\text { III. } \\
\text { MIS-fázis }\end{array}$ & $\begin{array}{l}\text { - Multiszisztémás } \\
\text { gyulladás és } \\
\text { többszervi } \\
\text { érintettség* }\end{array}$ & $\begin{array}{l}\text { - Klinikai: láz (>38,5C), légzési elégtelenség, } \\
\text { ARDS, szívelégtelenség, hipotenzió/sokk, } \\
\text { makrofágaktivációs szindróma, vérzékenység, } \\
\text { MOF (tüdő, szív, máj, vese, idegrendszer, } \\
\text { csontveló) } \\
\text { - CT: fehér tüdő } \\
\text { - Labor: ferritin } \geq 700 \mu \mathrm{g} / 1 \text {; lymphopenia, neut- } \\
\text { rophilia, D-dimer } \geq 1500 \mu \mathrm{g} / 1, \mathrm{CRP} \geq 150 \mathrm{mg} / 1 \text {, } \\
\text { LDH } \geq 400 \mathrm{U} / 1, \mathrm{GOT} \geq 100 \mathrm{U} / 1, \mathrm{IL} 6 \geq 15 \mathrm{pg} / \mathrm{ml} \text {, } \\
\text { vesefunkció-romlás, cTn és NT-proBNP tovább } \uparrow \text {, } \\
\text { PCT } \uparrow \text { (bakteriális szuperinfekció) }\end{array}$ & $\begin{array}{l}\text { - Kórbázi/ITO-kezelés } \\
\text { - Kortikoszteroid (1. dexametazon, 2. metil- } \\
\text { prednizolon) } \\
\text { - Ha kortikoszteroidra nem reagál a beteg: } \\
\text { citokingátlók (tocilizumab, anakinra, } \\
\text { baricitinib, sarilumab) } \\
\text { - kombináció: baricitinib + remdesivir } \\
\text { - hIVIG }\end{array}$ \\
\hline
\end{tabular}

*MIS: az összes eset 2\%-a, a súlyos esetek 8-11\%-a.

ARDS = akut légzési distressz szindróma; $\mathrm{ASA}=$ acetilszalicilsav; $\mathrm{CRP}=\mathrm{C}$-reaktív protein $\mathrm{CT}=$ számítógépes tomográfia; $\mathrm{cTn}=$ cardialis troponin; $\mathrm{FiO}_{2}=$ a belégzett oxigén koncentrációja; $\mathrm{GGO}$ = tejüvegszerú homály; GOT = glutamát-oxálacetát-transzamináz; hIVIG = humán intravénás immunglobulin; IL6 = interleukin-6; ITO = intenzív terápiás osztály; LDH = laktátdehidrogenáz; LMWH = kis molekulatömegú heparin; MIS = multiszisztémás inflammatorikus szindróma; $\mathrm{MOF}=$ sokszervi elégtelenség; NT-proBNP = N-terminális pro-B-típusú natriureticus peptid; $\mathrm{PaO}_{2}=$ parciális oxigénnyomás; $\mathrm{PCR}$ = polimeráz-láncreakció; $\mathrm{PCT}$ = prokalcitonin; $\mathrm{SaO}_{2}=$ oxigéntelítettség; SARS-CoV-2 = súlyos akut légúti tünetegyüttest okozó koronavírus-2

nösen fontosak, szükségesek a MIS igazolására $[5,6]$, és a fontosabb biomarkerek (például CRP, IL6, D-dimer) szintje összefügg az ITO-ellátás szükségességével és a kimenetellel (túlélés) is $[8,9]$. A kiindulási IL6-szint mérése nem kötelező, ez a biomarker számos intézményben nem érhető el, ez esetben elegendő a CRP, ferritin és D-dimer meghatározása. Nagyon fontos, hogy citokinvihar csak a betegek 2\%-ában, a súlyos betegek 8-11\%ában alakul ki. A betegek többségében nem emelkedett a citokinszint [10], és általában a cytokinaemia COVID19-ben kevésbé kifejezett, mint non-COVID-ARDSben [10-12]. A citokinek (például IL6) szintjét összefüggésbe hozták a betegség súlyosságával, az ITO-ba helyezés szükségességével és a kimenetellel [9-11]. A citokinvihart/MIS-t tehát igazolni kell, mert - mint lát- ni fogjuk - az immunszuppresszív terápiák is csak ebben a betegcsoportban hatékonyak $[2,5,7,9,10]$. Végül, a prokalcitonin (PCT) mérése szükséges lehet a bakteriális szuperinfekció igazolására (1. táblázat).

\section{A COVID-19 kezelésére alkalmazott gyógyszerek}

\section{Az algoritmus alapját képezö bizonyitékok (vázlatosan)}

Leszögezzük, hogy azokból a magas értékü, randomizált, kontrollált vizsgálatokból, amelyeket a gyógyszerek törzskönyvezéséhez használnak, igen keveset végeztek. 
A legtöbbször nem kontrollált vagy kisebb vizsgálatok érhetők el, néhány kivétellel (például RECOVERY). Ismeretes azonban, hogy a COVID-19-ben a sürgető tényezők miatt sürgősségi használati engedélyeztetés (emergency use authorization, EUA) is történik, ezért a jó minőségű, de alacsonyabb evidenciaszintű vizsgálatok eredményeit is figyelembe kell vennünk. Ajánlásunk tehát bizonyítékokon és szakértői véleményen (expert opinion) alapszik. A készítményeket ajánlott, megfontolható és nem javasolt szerekre osztottuk.

\section{Ajánlott készitmények}

Az antivirális szerek első vonalába tartozó szintetikus készítmények (favipiravir, remdesivir) más típusú vírusfertőzésekben bizonyítottak, és COVID-19-ben is sikerrel alkalmazhatók a korai szakaszban (I-IIB). A remdesivir csökkentette a gyógyulási időt $[13,14]$. Vannak adatok lopinavir-ritonavir kezeléssel kapcsolatban is, de egy nagyobb vizsgálatban (RECOVERY) ez a kezelés nem csökkentette a 28 napos halálozást és a kórházi ápolás idejét [15]. Késői szakaszban azonban a remdesivir nem volt hatásos önmagában a standard kezeléshez képest [16]. A remdesivir az Amerikai Egyesült Államok Élelmiszer-biztonsági és Gyógyszerészeti Hivatalától (FDA) EUA-engedélyt kapott [17], és az Európai Gyógyszerhatóság is törzskönyvezte.

A biológiai (fehérje) típusú antivirális szerek közül hatékonynak bizonyult a tüskefehérje-ellenes (anti-spike protein) antitest bamlanivimab (LY-CoV555), mely gátolja a vírus sejtbe jutását, és neutralizálja azt. Enyhe és középsúlyos COVID-19-ben (I-IIA) csökkentette a vírusterhelést [18, 19]. Ezek alapján a bamlanivimab EUA-engedélyt kapott [17]. A bamlanivimab azon felnőtteknek és 12 éves vagy annál idősebb, legalább 40 kg-os fiatal felnőtteknek javasolt enyhe vagy közepesen súlyos tünetek esetén, a tünetek megjelenését követő 10 napon belül, akiknél fennáll a progresszió lehetősége és / vagy a kórházi kezelés kockázata (például krónikus társbetegségek) [20].

A gyógyult betegből nyert reconvalescens plazma vírusellenes antitesteket tartalmaz, ezért antivirális kezelésként fogható fel. Korábban számos fertózéses állapotban alkalmazták sikerrel (például SARS-CoV-1, MERS) [21]. Használata azon a meggondoláson alapszik, hogy COVID-19-betegekben a SARS-CoV-2 elleni IgG magasabb plazmaszintje alacsonyabb halálozással járt együtt [22]. Viszonylag limitált mennyiségű adat alapján klinikai vizsgálatokban csökkentette a vírusterhelést, javította az oxigenizációt, a radiológiai képet és esetenként a túlélést [21, 23]. Enyhe fertőzéses esetekben, idősekben, korán alkalmazva meggátolta a betegség progresszióját [24]. Súlyos, előrehaladott COVID-19-pneumoniában azonban nem javította a klinikai statust és a mortalitást [25]. A reconvalescens plazma is megkapta az FDA EUA-engedélyét [17]. Az Európai Reumatológiai Társaság (EULAR) immunglobulin-deficiens betegekben különösen ajánlja ezt a kezelési módot [11]. Korai szakaszban (I-IIA) a leghatékonyabb, míg hypoxiával járó pneumonia eseteiben (IIB-III.) már kevéssé hatékony.

A gyulladásgátló, immunszuppresszín szerek a fokozódó szisztémás gyulladás, citokinvihar/MIS esetén vethetők be. Ezeket a szereket gyulladásos reumatológiai kórképek kezelésére (is) alkalmazzák, onnan kerültek átvételre (repurposing) $[1,5,11,26]$. Kórházi kezelést nem igénylő (I. stádium) és/vagy kórházban kezelt, de oxigénterápiát nem igénylő (IIA stádium) betegekben az immunszuppresszív kezelés jelenleg nem ajánlott [11]. A tartós immunszuppressziót igénylő esetekben (például szerv- és szövettranszplantáltak) az immunszuppresszió csökkentése a centrumok protokollja szerint javasolt.

A kortikoszteroidok az I-IIA fázisban nem javasoltak, mert retrospektív, autoimmun betegeken végzett vizsgálatokban a korábbi tartós kortikoszteroidkezelés fokozta a COVID-19 iránti fogékonyságot és a betegség súlyosságát [27]. A RECOVERY-vizsgálatban az oxigénterápiát nem igénylő alcsoportban a dexametazon még rontotta is a túlélést [28]. A már kialakult COVID-19 súlyosabb eseteiben (IIB-III. stádium) azonban a dexametazon szignifikánsan csökkentette a 28 napos halálozást. A hatékonyság jobb volt azokban, akiket invazívan kellett lélegeztetni. Enyhébb hatást észleltek azokban, akik enyhe-középsúlyos pneumonia miatt nem invazív oxigénterápiát kaptak [11, 28]. A kórházi halálozást és a klinikai kimenetelt a metilprednizolon is javította a CHIC-vizsgálatban azokban, akikben kifejezett CRP-, D-dimer- és ferritinemelkedés volt (1. táblázat) [29]. Végeredményben a kortikoszteroidot a legtöbb protokoll ajánlja középsúlyos, oxigéninhalációt igénylő (IIB) és súlyos, ITO-n lélegeztetett (III.) betegekben is [11]. Kis dózisú metilprednizolon a IIA stádiumban is megpróbálható. A IIB-III. stádiumban egyelőre nincs bizonyíték, hogy különböző kortikoszteroidadagolás lenne szükséges az alacsonyabb (1-2 1/perc), illetve a magasabb (3-15 1/perc) oxigénterápia mellett [11]. A dexametazon is megkapta az FDA EUA-engedélyét [17].

Az IL6-receptor (IL6R)-gátló tocilizumab több vizsgálatban hatékonynak bizonyult, különösen, amikor IIB-III. stádiumban (súlyos, ITO-kezelést igénylő esetek) alkalmazták [8, 29-32]. Az ideális időablak a tünetek kezdetétól legalább 7 nap, de a súlyosbodástól legfeljebb 14 nap [1, 26, 33]. A tocilizumab javította a túlélést és az ITO-ról, valamint a kórházból való elbocsátás esélyét [31], ezen belül csökkentette a lázat, a CRP-t, javította az oxigenizációt és a vérképet (lymphopenia) [30]. A REMAP-CAP-vizsgálatban az ITO-ra utalást követő két napon belül, hamar alkalmazva a tocilizumabot a szer annyira hatékony volt, hogy a vizsgálatot idő elött fel lehetett függeszteni [34]. „Mellékhatásként” a tocilizumab a vérben átmenetileg növelte a szabad IL6-szintet, ezért az IL6-szint meghatározása csak kiinduláskor javasolt [8]. A CHIC-vizsgálatban a kezdetben kortikoszteroiddal kezelt, de arra nem megfelelően reagáló betegekben a tocilizumab hozzáadott (add-on) terápiakánt javí- 
totta a klinikai képet és a túlélést [29]. Az eddigi legnagyobb COVID-19-terápiás vizsgálatban (RECOVERY; 4116 beteg) invazív lélegeztetésre, nem invazív oxigénterápiára és egyikre sem szoruló (kontrollcsoport) betegeket vizsgáltak. Kiinduláskor a betegek $82 \%$-a kortikoszteroidot kapott. A kórházi kezelést igénylő, hypoxiás (IIB-III. stádiumú) betegekben a tocilizumab csökkentette a halálozást, javította a kórházból élve hazabocsátás esélyét. Az invazív lélegeztetést nem igénylőkben csökkentette a halálozást és a respirátorkezelés szükségességét [35]. A tocilizumab hazai betegekben is hatékonynak bizonyult [33]. Ezzel szemben a szponzor által végzett nagy, COVACTA III. fázisú vizsgálatban az elsődleges (klinikai javulás) és a másodlagos (halálozás) végpont nem teljesült, csupán mérsékelt javulást észleltek a kórházi elbocsátás tekintetében [36, 37]. Megjegyzendő, hogy a bevonás a COVID-19 ténye és az oxigenizáció alapján történt, időablakot és biomarkereket nem alkalmaztak [37]. Több másik vizsgálatban pneumoniás, oxigént vagy igénylő, vagy nem, de ITO-kezelést nem igénylö, enyhe-középsúlyos betegekben (IIA-IIB stádium) a tocilizumab szintén nem csökkentette a mortalitást [38-40]. Míg az ilyen középsúlyos betegek egyharmadában a gyógyszer csökkentette az invazív lélegeztetés szükségességét (CORIMUNO-19-vizsgálat) [49]. Összességében a tocilizumab rutinszerü alkalmazását a IIB-III. stádiumban nem javasolják, de kortikoszteroidra nem reagáló, igazolt MIS-ben szenvedő betegcsoportokban igen $[11,29]$. Ilyenkor a kortikoszteroid folytatása mellett kombinációban javasolt hozzáadni a tocilizumabot [11, 29]. A tocilizumabbal ezen célzott, homogén betegcsoportokban további randomizált, kontrollált tanulmányok végzése szükséges [11].

A Janus-kináz (JAK)-gátlók közül a baricitinib a JAKl és JAK2 izoformákat gátolja, emiatt több citokin (például IL2, IL4, IL6, interferon- $\gamma$ ) szignalizációját gátolja [41, 42]. Antivirális hatása révén a vírus sejtbe történó penetrációját is gátolja [43]. Kisebb vizsgálatokban COVID-19-ben csökkentette az IL6-szintet, valamint normalizálta a lymphocytaszámot, ezen belül a $\mathrm{CD}^{+}{ }^{+}$és $\mathrm{CD}^{+}$T-sejt-, valamint B-sejt-számot [42]. A baricitinib remdesivirrel kombinációban súlyos, respirátorkezelést igénylő (IIB-III. stádiumú) betegekben szignifikánsan javította a klinikai statust, és csökkentette a gyógyulásig eltelt időt. Enyhe-középsúlyos, illetve moribund betegekben nem észleltek hatékonyságot [44]. Az FDA ez alapján EUA-engedélyt adott e kombináció használatára súlyos COVID-19-ben (IIB-III.) [17, 45], és az EULAR is ajánlja ezt a kombinációt a IIB-III. stádiumban [11]. (Önmagában csak az egyéb alkalmazható készítmények közé sorolható.)

A több szervben létrejövő microthrombusok és a COVID-19-cel összefüggő thromboembolia rizikója miatt [46] a betegeknek acetilszalicilsavat (aszpirin 100 mg, kis molekulatömegű heparint (LMWH) vagy új típusú orális antikoagulánst (NOAC) javasolt adagolni legalább profilaktikus dózisban kiegészítésül [3]. Az an- tithromboticus és antikoaguláns kezelés részletes ismertetése nem ezen ajánlás feladata. Ezeket a szereket a profilaxis mellett, kialakult thromboemboliás állapotban, terápiásan is alkalmazzák és monitorozzák a szakma szabályai szerint.

\section{Egyéb alkalmazható készitmények}

Az antivirális antitestek közül a bamlanivimabon túl kifejlesztették az etesivimab 'anti-spike' antitestet, mely bamlanivimabbal kombinációban igen hatékony volt [19]. Ezek alapján az etesivimab és további két, egymással kombinációban alkalmazandó 'anti-spike' antitest (REGEN-COV: casirivimab és imdevimab) EUA-engedélyt kapott [17]. Ezek a szerek az ajánlás írásakor egyelőre nem érhetők el.

Az ún. autoinflammatio (NLRP3-inflammaszómaaktiváció, IL1 $\beta$-termelés) szerepét is igazolták COVID19-ben. Az ILl-receptor-antagonista (IL1Ra) anakinra súlyos betegségben (IIB-III. stádium) szintén javította a túlélést [47]. Az anakinra pneumoniás, kórházban kezelt betegekben korán alkalmazva, kortikoszteroid nélkül vagy kortikoszteroiddal kombinálva, szintén hatékonynak bizonyult [48]. Ezzel szemben az említett CORIMUNO-19-vizsgálatban, akiknél hypoxia volt, de a betegek nem szorultak lélegeztetésre (IIB stádium), az anakinra nem mutatott hatékonyságot [49]. Középsúlyos esetekben az anakinra szintén hatástalannak bizonyult [11]. Korai vizsgálatok történtek az anti-IL1 $\beta$ antitest canakinumabbal is [50], de a futó randomizált, kontrollált tanulmányok eredményeit még nem publikálták. Mindenesetre nagyobb, randomizált, kontrollált tanulmányok hiányában ezen szereket egyelőre rutinszerúen nem javasolják. A kifejezett MIS eseteiben a tocilizumab hatástalansága esetén alkalmazása megfontolandó [11].

A szintén IL6R-gátló sarilumab III. stádiumú betegekben szintén javította a túlélést, valamint az ITO-ról és a kórházból való elbocsátás esélyét $[31,34]$. Ezzel szemben a SARI-RAF kisebb tanulmányban pneumoniás, magas gyulladásos értékeket mutató, de invazív lélegeztetést nem igénylő (IIB stádium) betegeket kezelve nem észleltek klinikai javulást és hosszabb túlélést a standard kontrollal szemben. A betegek kevésbé súlyosak voltak, és relatíve alacsonyabb életkoruk és IL6- és D-dimer-szintjük volt, ami magyarázhatta a hatástalanságot [51]. A szponzor által folytatott nagy, III. fázisú vizsgálatban a sarilumab ugyancsak nem teljesítette a kitüzött végpontokat, csupán numerikusan javult a kórházi elbocsátás aránya [52]. A sarilumabot szintén tovább kell vizsgálni célzott, homogén betegcsoportokban [11].

A JAK-gátlók közül a már említett baricitinib remdesivirrel ajánlott $[42,43]$. Egyébként ebbe a csoportba tartozik a ruxolitinib JAK2-gátló is, melyet hematológiai malignitások kezelésére alkalmaznak. Kisebb klinikai vizsgálatokban mérsékelten hatékonynak bizonyult 
COVID-19-ben is, elsősorban tocilizumabra nem reagáló esetekben $[53,54]$.

A nagy dózisú, bumán intravénás immunglobulin (hIVIG) COVID-19-ben történő alkalmazására vonatkozóan nagyon kevés megbízható vizsgálat történt. Egy 59 betegen történt kontrollált tanulmányban a kezdeti kezelés sikertelensége után alkalmazott hIVIG klinikai javulást eredményezett [55], de egy hasonló tervezésú vizsgálatban a hIVIG más antivirális szerekkel kombinálva nem volt hatékony [56]. A hIVIG alkalmazása immunmoduláns hatása révén elsősorban a MIS fázisában jöhet szóba, de igen drága, és hatékonysága nem vetekszik a kortikoszteroidéval, illetve citokingátlókéval. Emellett potenciálisan védhet a bakteriális felülfertőződés ellen $[1,26]$. Ultimum refugiumként, kritikus esetekben megpróbálható $[1,26]$. A hIVIG-terápia megkezdése előtt nem szükséges immunglobulinszintet nézni.

\section{Nem javasolt készitmények}

Korábban több más szer (azitromicin, hidroxiklorokin, interferonok, leflunomid, ciklosporin A, eculizumab, ivermektin, melatonin, fluvoxamin, N-acetil-cisztein, kvercetin, BCG stb.) esetében felvetődött hatás, de valódi bizonyítékok híján, illetve mellékhatásaik miatt (például hidroxiklorokin, ivermektin) ezek egyelőre, hiteles evidenciák hiányában nem javasoltak $[4,11]$. A jövőben további kontrollált vizsgálatok szükségesek, ha bármelyik fenti szer hatását igazolni kívánják. Külön kiemelendő, hogy a korábban favorizált hidroxiklorokin több randomizált, kontrollált tanulmányban hatástalan volt enyhe-középsúlyos esetekben. Súlyos esetekben pedig kifejezetten rontotta a prognózist $[11,57]$. A korábban szinte rutinszerúen alkalmazott azitromicinról is kiderült a RECOVERY-vizsgálatban, hogy a COVID-19-re hatástalan, így csak bakteriális szuperinfekció esetén javasolják, más antibiotikumokhoz hasonlóan [58]. Külön kiemelendő, hogy a - helytelenül - gyakran profilaktikusan alkalmazott antibiotikumkezelés fokozza a bakteriális rezisztenciát és a Clostridium-fertőzés rizikóját, ezért nem ajánlott [58].

A terápia meghatározása kiinduláskor, a SARS-CoV2-fertőzés igazolása mellett, a klinikai tünetek (elsősorban a láz és légúti tünetek), az oxigenizációs index (Horowitzindex: $\left.\mathrm{PaO}_{2} / \mathrm{FiO}_{2}\right)$, a mellkasi képalkotó vizsgálatok, laboratóriumi biomarkerek (vérkép, CRP, D-dimer, ferritin, LDH, GOT, cTn és kiinduláskor, MIS-gyanú esetén IL6szint, amennyiben elérhető) alapján történik. A terápia a klinikai tünetek, a Horowitz-index, a képalkotó és bizonyos biomarkerek (CRP, D-dimer, vérkép [a lymphopenia mértéke], esetleg ferritin) követésével történjen [1, 2, $5,7]$.

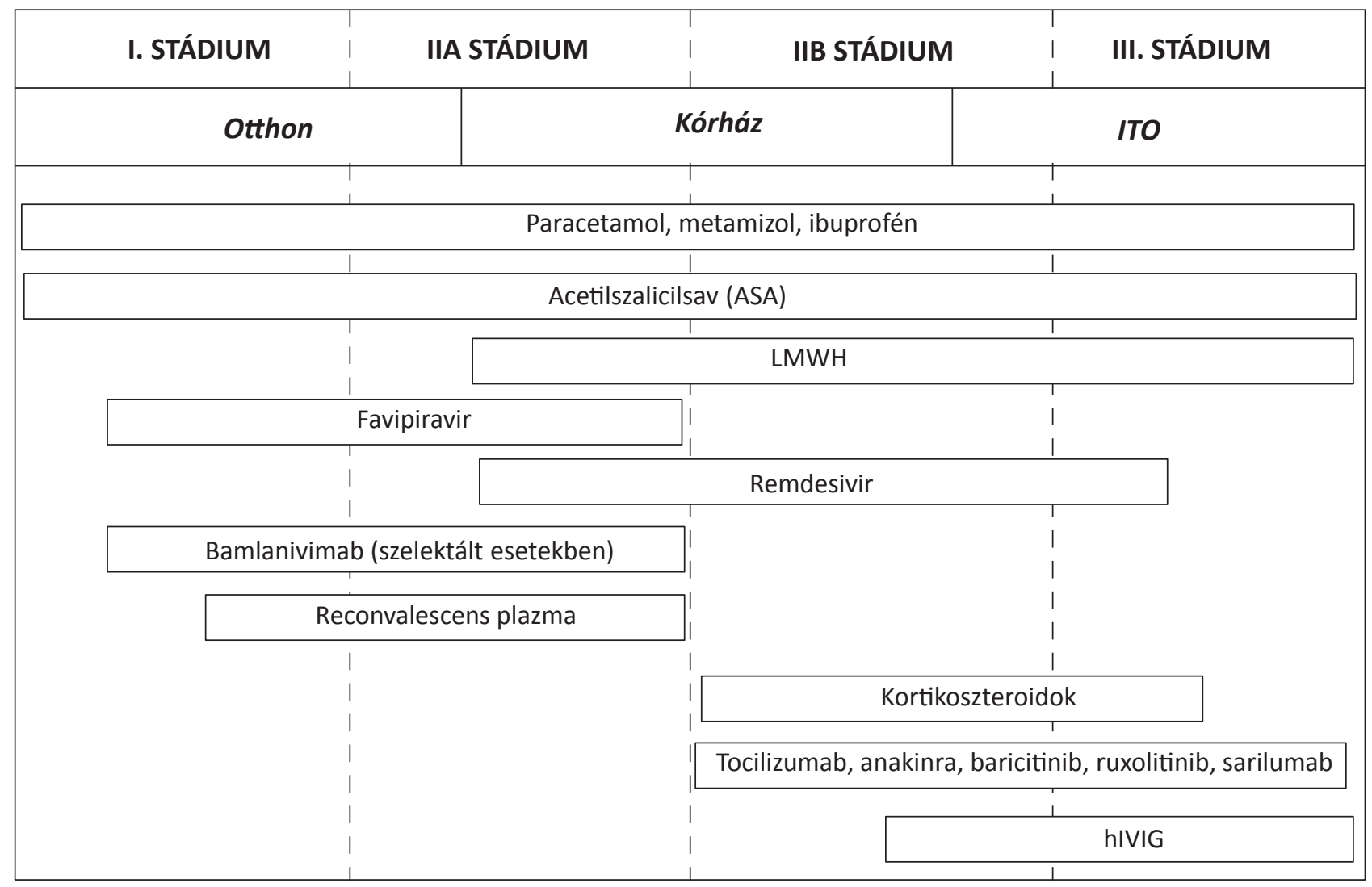

ASA = acetilszalicilsav; COVID-19 = koronavírus-betegség 2019; hIVIG = humán intravénás immunglobulin; ITO = intenzív terápiás osztály; $\mathrm{LMWH}=$ kis molekulatömegű heparin 
2. táblázat |A COVID-19 kezelésére alkalmazott gyógyszerek (súlyossági sorrendben)*

\begin{tabular}{|c|c|c|c|c|}
\hline Gyógyszer & Hatás & Adagolás & Javallat & Megjegyzés \\
\hline \multicolumn{5}{|c|}{ Ajánlott készitmények } \\
\hline Favipiravir & Antivirális & $\begin{array}{l}\text { Per os } 2 \times 1600 \mathrm{mg} \text { az } 1 . \text { napon, majd } 2 \times 600 \mathrm{mg} \\
\text { a } 2-5 \text {. napon (lehet adni } 14 \text { napig is) }\end{array}$ & I-IIA & $\begin{array}{l}67 / 2020 \text { (III. 26.) Korm. } \\
\text { rendelet OGYÉI-engedély }\end{array}$ \\
\hline Remdesivir & Antivirális & $\begin{array}{l}\text { Iv. } 200 \mathrm{mg} \text { az } 1 . \text { napon, } \\
\text { majd } 100 \mathrm{mg} \text { a } 2-10 . \text { napon }\end{array}$ & II-III. & $\begin{array}{l}\text { FDA: hypoxiával járó } \\
\text { pneumonia esetén }\end{array}$ \\
\hline Bamlanivimab & $\begin{array}{l}\text { Antivirális } \\
\text { (biologikum) }\end{array}$ & Iv. $1 \times 700 \mathrm{mg}$ & I-IIA & $\begin{array}{l}\text { Szelektált esetekben, az } \\
\text { elérhetőség függvényében }\end{array}$ \\
\hline $\begin{array}{l}\text { Reconvalescens } \\
\text { plazma }\end{array}$ & $\begin{array}{l}\text { Antivirális (antiteste- } \\
\text { ket tartalmaz) }\end{array}$ & $\begin{array}{l}\text { Iv. } 2 \mathrm{E} \text { (egység) }(400 \mathrm{ml} \\
\text { vagy } 1 \mathrm{E}(200 \mathrm{ml}) \text { ismételve })\end{array}$ & $\mathrm{I}-\mathrm{IIB}$ & $\begin{array}{l}\text { Megfelelően magas titerű } \\
\text { plazmával }\end{array}$ \\
\hline Dexametazon & $\begin{array}{l}\text { Gyulladásgátló } \\
\text { (kortikoszteroid) }\end{array}$ & Per os/iv. $6 \mathrm{mg}$ (<10 napig) & IIB-III. & \\
\hline $\begin{array}{l}\text { Metilprednizo- } \\
\text { lon }\end{array}$ & $\begin{array}{l}\text { Gyulladásgátló } \\
\text { (kortikoszteroid) }\end{array}$ & $\begin{array}{l}\text { Iv. } 250 \mathrm{mg} \text { (1. nap), majd } 80 \mathrm{mg}(2-5 . \text { nap) vagy } \\
0,5-1 \mathrm{mg} / \mathrm{kg} / \text { nap max. } 7 \text { napig }\end{array}$ & IIB-III. & $\begin{array}{l}\text { Szükség esetén kis } \\
\text { dózisban IIA-ban is adható }\end{array}$ \\
\hline Tocilizumab & $\begin{array}{l}\text { Biologikum } \\
\text { (anti-IL6R) }\end{array}$ & $\begin{array}{l}\text { Iv. } 4-8 \mathrm{mg} / \mathrm{kg}, \text { max. } 800 \mathrm{mg} \text { egy alkalommal, } \\
\text { szükség esetén > } 12 \text { óra múlva egyszer ismételhető }\end{array}$ & IIB-III. & $\begin{array}{l}\text { Igazolt MIS és kortikoszte- } \\
\text { roid hatástalansága esetén }\end{array}$ \\
\hline Baricitinib & JAK-gátló & $\operatorname{Per}$ os $4 \mathrm{mg} / \mathrm{nap}$ & $\begin{array}{l}\text { IIB-III. (remdesi- } \\
\text { virrel kombináció- } \\
\text { ban ajánlott) }\end{array}$ & $\begin{array}{l}\text { Igazolt MIS és kortikoszte- } \\
\text { roid hatástalansága esetén }\end{array}$ \\
\hline \multicolumn{5}{|c|}{ Egyéb alkalmazható készitmények } \\
\hline Anakinra & Biologikum (IL1Ra) & $\begin{array}{l}\text { Sc. INJ } 3-4 \times 100 \mathrm{mg} / \mathrm{nap} \text {, } \\
\text { max. } 15 \text { napig }\end{array}$ & IIB-III. & $\begin{array}{l}\text { Igazolt MIS és kortikoszte- } \\
\text { roid hatástalansága esetén }\end{array}$ \\
\hline Ruxolitinib & JAK-gátló & Per os $2 \times 10 \mathrm{mg} / \mathrm{nap}$ & IIB-III. & $\begin{array}{l}\text { Igazolt MIS és kortikoszte- } \\
\text { roid hatástalansága esetén }\end{array}$ \\
\hline Sarilumab & $\begin{array}{l}\text { Biologikum } \\
\text { (anti-IL6R) }\end{array}$ & Iv. $200-400 \mathrm{mg}$ & IIB-III. & $\begin{array}{l}\text { Igazolt MIS és kortikoszte- } \\
\text { roid hatástalansága esetén }\end{array}$ \\
\hline hIVIG & $\begin{array}{l}\text { Humán immun- } \\
\text { globulin }\end{array}$ & Iv. $0,5-1 \mathrm{~g} / \mathrm{kg} /$ nap 5 napig & $\begin{array}{l}\text { III. (refrakter } \\
\text { esetekben) }\end{array}$ & $\begin{array}{l}\text { Refrakter, szelektált } \\
\text { esetekben }\end{array}$ \\
\hline
\end{tabular}

*Emellett: azitromicin (bakteriális szuperinfekció esetén [PCT javasolt], $500 \mathrm{mg} / \mathrm{nap} 5 \mathrm{napig}$ ), ASA (napi $100 \mathrm{mg}$ ), LMWH (50 IU/kg), szupportív szerek.

ASA $=$ acetilszalicilsav; FDA = az Amerikai Egyesült Államok Élelmiszer-biztonsági és Gyógyszerészeti Hivatala; hIVIG = humán intravénás immunglobulin; IL = interleukin; ILlRa = interleukin-1-receptor-antagonista; IL6R = interleukin-6-receptor; INJ = injekció; iv. = intravénás; JAK = Janus-kináz; LMWH = kis molekulatömegű heparin; MIS = multiszisztémás inflammatorikus szindróma; OGYÉI = Országos Gyógyszerészeti és Élelmezés-egészségügyi Intézet; PCT = prokalcitonin; sc. = subcutan

A COVID-19 enyhe esetekben, akár 2 héten belül meggyógyulhat. A 3 hétnél tovább húzódó betegséget poszt-COVID-szindrómának, a COVID-19 és az utóbbi összességét long-COVID-nak hívják. Nincs bizonyíték egyetlen gyógyszer hatékonyságára sem ebben az állapotban. Gondozás, multidiszciplináris követés és tüneti kezelés ajánlott $[59,60]$.

\section{A bizonyítékokon alapuló lehetséges algoritmus}

Az eddig ismertetett bizonyítékok és ajánlások alapján javasolt algoritmust $[2,3,7,61]$ a 2 ábra mutatja.

Az 1. és a 2. táblázat mutatja az egyes szakaszok kritériumait és az alkalmazott gyógyszerek ajánlott dózisát. $\mathrm{Az}$ egyes COVID-centrumok alkalmazhatnak egyéni protokollokat az általános elvek mentén. Általánosságban még elmondható:
- A láz- és fájdalomcsillapítók és a kis dózisú acetilszalicilsav szedése végig javasolt.

- Az antivirális kezelés a beteg otthonában favipiravirral javasolt az első vonalban.

- Reconvalescens plazma és bamlanivimab elsősorban korán, az I-IIA fázisban javasolt.

- A remdesivir kórházi körülmények között alkalmazandó.

- MIS jelei esetében (1. táblázat) elóször kortikoszteroid adása javasolt, ezen belül a dexametazon preferált, de metilprednizolon is szóba jön.

- Ha a kortikoszteroid 3-5 nap után nem eléggé hatékony, citokingátló javasolt (elsősorban tocilizumab, ennek hatástalansága esetén anakinra, baricitinib, ruxolitinib) a kortikoszteroid mellett.

- Ha a beteg korábban már kapott remdesivirt, akkor a remdesivir folytatása és baricitinib kombinálása javasolt.

- A hIVIG inkább a fenti szerekre refrakter esetekben javasolt. 
Anyagi támogatás: A közlemény megírása anyagi támogatásban nem részesült.

Szerzői munkamegosztás: Sz. Z.: A hipotézisek kidolgozása, a kézirat megszövegezése. B. K., C. T., F. B., R. É., V. I.: A kézirat megszövegezése. M. V., V.-N. I.: A hipotézisek kidolgozása, a kézirat megszövegezése. A cikk végleges változatát valamennyi szerző elolvasta és jóváhagyta.

Érdekeltségek: A szerző́knek nincsenek érdekeltségeik.

\section{Irodalom}

[1] Szekanecz Z, Bálint P, Balog A, et al. Immunologic and rheumatologic aspects of COVID-19. [A COVID-19 fertőzés immunológiai és reumatológiai vonatkozásai.] Immunol Szle. 2020; 12(2): 5-17. [Hungarian]

[2] Siddiqi HK, Mehra MR. COVID-19 illness in native and immunosuppressed states: a clinical-therapeutic staging proposal. J Heart Lung Transplant. 2020; 39: 405-407.

[3] Handbook of prevention and therapy of novel coronavirus (SARS-CoV-2) infection identified in 2020. [A 2020. évben azonosított új koronavírus (SARS-CoV-2) okozta fertőzések (COVID-19) megelőzésének és terápiájának kézikönyve. 3. kiadás.] Emberi Erőforrások Minisztériuma, Budapest, 2020. december 18. [Hungarian]

[4] World Health Organization. COVID-19 clinical management: living guidance. WHO, Geneva, Jan 25, 2021. Available from: https://www.who.int/publications/i/item/WHO-2019. nCoV-clinical-2021-1 [accessed: ].

[5] Szekanecz Z, Bálint P, Balog A, et al. COVID-19: cytokine storm and beyond. [COVID-19: a citokinviharon innen és túl ...] Immunol Szle. 2020; 12(4): 5-15. [Hungarian]

[6] Webb BJ, Peltan ID, Jensen P, et al. Clinical criteria for COVID 19-associated hyperinflammatory syndrome: a cohort study. Lancet Rheumatol. 2020; 2: e754-e763

[7] Gandhi RT, Lynch JB, Del Rio C. Mild or moderate COVID-19. N Engl J Med. 2020; 383: 1757-1766.

[8] Sciascia S, Apra F, Baffa A, et al. Pilot prospective open, singlearm multicentre study on off-label use of tocilizumab in patients with severe COVID-19. Clin Exp Rheumatol. 2020; 38: 529532

[9] Mojtabavi H, Saghazadeh A, Rezaei N. Interleukin-6 and severe COVID-19: a systematic review and meta-analysis. Eur Cytokine Netw. 2020; 31: 44-49.

[10] Mudd PA, Crawford JC, Turner JS, et al. Distinct inflammatory profiles distinguish COVID-19 from influenza with limited contributions from cytokine storm. Sci Adv. 2020; 6: eabe3024.

[11] Alunno A, Najm A, Machado PM, et al. EULAR points to consider on pathophysiology and use of immunomodulatory therapies in COVID-19. Ann Rheum Dis. 2021 Feb 5. [Online ahead of print]

[12] Kox M, Waalders NJB, Kooistra EJ, et al. Cytokine levels in critically ill patients with COVID-19 and other conditions. JAMA 2020; 324: 1525-1527.

[13] Martinez MA. Clinical trials of repurposed antivirals for SARS CoV-2. Antimicrob Agents Chemother. 2020; 64: e01101-20.

[14] Beigel JH, Tomashek KM, Dodd LE, et al. Remdesivir for the treatment of Covid-19 - final report. N Engl J Med. 2020; 383 : 1813-1826.

[15] RECOVERY Collaborative Group. Lopinavir-ritonavir in patients admitted to hospital with COVID-19 (RECOVERY): a randomised, controlled, open-label, platform trial. Lancet 2020; 396: $1345-1352$
[16] Consortium WHOST, Pan H, Peto R, et al. Repurposed antiviral drugs for COVID-19 - interim WHO Solidarity Trial results. N Engl J Med. 2021; 384: 497-511.

[17] U.S. Food and Drug Administration. Emergency use authorization. FDA, White Oak, MD, 2020. Available from: https:// www.fda.gov/emergency-preparedness-and-response/mcm-legal-regulatory-and-policy-framework/emergency-use-authorization [accessed: March 3, 2021].

[18] Chen P, Nirula A, Heller B, et al. SARS-CoV-2 neutralizing antibody LY-CoV555 in outpatients with COVID-19. N Engl J Med. 2021; 384: 229-237.

[19] Gottlieb RL, Nirula A, Chen P, et al. Effect of bamlanivimab as monotherapy or in combination with etesevimab on viral load in patients with mild to moderate COVID-19: a randomized clinical trial. JAMA 2021; 325: 632-644.

[20] An EUA for bamlanivimab. A monoclonal antibody for COVID-19. Med Lett Drugs Ther. 2020; 62: 185-186.

[21] Bloch EM, Shoham S, Casadevall A, et al. Deployment of convalescent plasma for the prevention and treatment of COVID-19. J Clin Invest. 2020; 130: 2757-2765.

[22] Joyner MJ, Carter RE, Senefeld JW, et al. Convalescent plasma antibody levels and the risk of death from COVID-19. N Engl J Med. 2021; 384: 1015-1027.

[23] Duan K, Liu B, Li C, et al. Effectiveness of convalescent plasma therapy in severe COVID-19 patients. Proc Natl Acad Sci USA 2020; 117: 9490-9496.

[24] Libster R, Perez Marc G, Wappner D, et al. Early high-titer plasma therapy to prevent severe COVID-19 in older adults. N Engl J Med. 2021; 384: 610-618.

[25] Simonovich VA, Burgos Pratx LD, Scibona P, et al. A randomized trial of convalescent plasma in COVID-19 severe pneumonia. N Engl J Med. 2021; 384: 619-629.

[26] Ferro F, Elefante E, Baldini C, et al. COVID-19: the new challenge for rheumatologists. Clin Exp Rheumatol. 2020; 38: 175180.

[27] Akiyama S, Hamdeh S, Micic D, et al. Prevalence and clinical outcomes of COVID-19 in patients with autoimmune diseases: a systematic review and meta-analysis. Ann Rheum Dis. 2021; 80: 384-391.

[28] RECOVERY Collaborative Group. Dexamethasone in hospitalized patients with COVID-19. Preliminary report. N Engl J Med. 2020; 384: 693-704.

[29] Ramiro S, Mostard RLM, Magro-Checa C, et al. Historically controlled comparison of glucocorticoids with or without tocilizumab versus supportive care only in patients with COVID19-associated cytokine storm syndrome: results of the CHIC study. Ann Rheum Dis. 2020; 79: 1143-1151.

[30] Xu X, Han M, Li T, et al. Effective treatment of severe COVID-19 patients with tocilizumab. Proc Natl Acad Sci USA 2020; 117 : 10970-10975.

[31] Gordon AC, Mouncey PR, Al-Beidh F, et al. Interleukin-6 receptor antagonists in critically ill patients with COVID-19. Preliminary report. N Engl J Med. 2021 Feb 25. Doi: 10.1056/ NEJMoa2 100433. [Epub ahead of print]

[32] Klopfenstein T, Zayet S, Lohse A, et al. Impact of tocilizumab on mortality and/or invasive mechanical ventilation requirement in a cohort of 206 COVID-19 patients. Int J Infect Dis. 2020; 99 : 491-495.

[33] Lakatos B, Gopcsa L, Gondos E, et al. Anti-cytokine therapy in novel coronavirus disease (COVID-19). The first administration of tocilizumab in Hungary at a department of infectology. [Citokinellenes terápia az új típusú koronavírus okozta megbetegedés (COVID-19) kezelésében - tocilizumab elsóként való alkalmazása egy hazai infektológiai osztályon.] Orv Hetil. 2020; 161: 1070-1077. [Hungarian]

[34] Gupta S, Wang W, Hayek SS, et al. Association between early treatment with tocilizumab and mortality among critically ill patients with COVID-19. JAMA Intern Med. 2021; 181: 41-51. 
[35] RECOVERY Collaborative Group. Tocilizumab in patients admitted to hospital with COVID-19 (RECOVERY): preliminary results of a randomised, controlled, open-label, platform trial. medRXiv 2021 Feb 11. [Doi: 10.1101/2021.02.11.21249258.]

[36] F. Hoffmann-La Roche Ltd. Roche provides an update on the phase III COVACTA trial of Actemra/RoActemra in hospitalised patients with severe COVID-19 associated pneumonia (press release). 29 July 2020. Available from: https://www. roche.com/investors/updates/inv-update-2020-07-29.htm [accessed: March 3, 2021]

[37] Furlow B. COVACTA trial raises questions about tocilizumab's benefit in COVID-19. Lancet Rheumatol. 2020; 2: e592.

[38] Stone JH, Frigault MJ, Serling-Boyd NJ, et al. Efficacy of tocilizumab in patients hospitalized with COVID-19. N Engl J Med. 2020; 383: 2333-2344.

[39] Hermine O, Mariette X, Tharaux PL, et al. Effect of tocilizumab vs usual care in adults hospitalized with COVID-19 and moderate or severe pneumonia: a randomized clinical trial. JAMA Intern Med. 2021; 181: 32-40.

[40] Salvarani C, Dolci G, Massari M, et al. Effect of tocilizumab vs standard care on clinical worsening in patients hospitalized with COVID-19 pneumonia: a randomized clinical trial. JAMA Intern Med. 2021; 181: 24-31.

[41] Winthrop KL, Yamanaka H, Valdez H, et al. Herpes zoster and tofacitinib therapy in patients with rheumatoid arthritis. Arthritis Rheumatol. 2014; 66: 2675-2684.

[42] Bronte V, Ugel S, Tinazzi E, et al. Baricitinib restrains the immune dysregulation in patients with severe COVID-19. J Clin Invest. 2020; 130: 6409-6416

[43] Tsai YC, Tsai TF. Oral disease-modifying antirheumatic drugs and immunosuppressants with antiviral potential, including SARS-CoV-2 infection: a review. Ther Adv Musculoskelet Dis. 2020; 12: $1759720 X 20947296$.

[44] Kalil AC, Patterson TF, Mehta AK, et al. Baricitinib plus remdesivir for hospitalized adults with COVID-19. N Engl J Med. 2021; 384: 795-807.

[45] U.S. Food and Drug Administration. Coronavirus (COVID-19) update: FDA authorizes drug combination for treatment of COVID-19. FDA, White Oak, MD, Nov 19, 2020. Available from: https://www.fda.gov/news-events/press-announcements/coronavirus-covid-19-update-fda-authorizes-drug-combination-treatment-covid-19 [accessed: March 3, 2021].

[46] Merrill JT, Erkan D, Winakur J, Jet al. Emerging evidence of a COVID-19 thrombotic syndrome has treatment implications. Nat Rev Rheumatol. 2020; 16: 581-589.

[47] Langer-Gould A, Smith JB, Gonzales EG, et al. Early identification of COVID-19 cytokine storm and treatment with anakinra or tocilizumab. Int J Infect Dis. 2020; 99: 291-297.

[48] Pontali E, Volpi S, Signori A, et al. Efficacy of early anti-inflammatory treatment with high doses of intravenous anakinra with or without glucocorticoids in patients with severe COVID-19 pneumonia. J Allergy Clin Immunol. 2021 Feb 6. S0091-
6749(21)00171-8. Doi: 10.1016/j.jaci.2021.01.024. [Online ahead of print]

[49] CORIMUNO-19 Collaborative Group. Effect of anakinra versus usual care in adults in hospital with COVID-19 and mild-tomoderate pneumonia (CORIMUNO-ANA-1): a randomised controlled trial. Lancet Respir Med. 2021; 9: 295-304.

[50] Landi L, Ravaglia C, Russo E, et al. Blockage of interleukin-1 $\beta$ with canakinumab in patients with COVID-19. Sci Rep. 2020; 10: 21775

[51] Della-Torre E, Campochiaro C, Cavalli G, et al. Interleukin-6 blockade with sarilumab in severe COVID-19 pneumonia with systemic hyperinflammation: an open-label cohort study. Ann Rheum Dis. 2020; 79: 1277-1285.

[52] Sanofi. Sanofi provides update on Kevzara ${ }^{\circledR}$ (sarilumab) phase 3 trial in severe and critically ill COVID-19 patients outside the U.S. (press release). Sep 1, 2020. Available from: https://www. sanofi.com/en/media-room/press-releases/2020/202009-01-07-00-00 [accessed: March 3, 2021].

[53] Innes AJ, Cook LB, Marks S, et al. Ruxolitinib for tocilizumabrefractory severe COVID-19 infection. Br J Haematol. 2020; 190: e198-e200

[54] Cao Y, Wei J, Zou L, et al. Ruxolitinib in treatment of severe coronavirus disease 2019 (COVID-19): a multicenter, singleblind, randomized controlled trial. J Allergy Clin Immunol. 2020; 146: 137-146.e3.

[55] Gharebaghi N, Nejadrahim R, Mousavi SJ, et al. The use of intravenous immunoglobulin gamma for the treatment of severe coronavirus disease 2019: a randomized placebo-controlled double-blind clinical trial. BMC Infect Dis. 2020; 20: 786.

[56] Tabarsi P, Barati S, Jamaati H, et al. Evaluating the effects of intravenous immunoglobulin (IVIg) on the management of severe COVID-19 cases: a randomized controlled trial. Int Immunopharmacol. 2021; 90: 107205.

[57] RECOVERY Collaborative Group. Effect of hydroxychloroquine in hospitalized patients with Covid-19. N Engl J Med. 2020; 383: 2030-2040.

[58] RECOVERY Collaborative Group. Azithromycin in patients admitted to hospital with COVID-19 (RECOVERY): a randomised, controlled, open-label, platform trial. Lancet 2021; 397: 605-612.

[59] Marshall M. The lasting misery of coronavirus long-haulers. Nature 2020; 585: 339-341

[60] Greenhalgh T, Knight M, A'Court C, et al. Management of postacute COVID-19 in primary care. BMJ 2020; 370: m3026.

[61] Galluccio F, Ergonenc T, Garcia Martos A, et al. Treatment algorithm for COVID-19: a multidisciplinary point of view. Clin Rheumatol. 2020; 39: 2077-2084.

(Szekanecz Zoltán dr., Debrecen, Nagyerdei krt. 98., 4032 e-mail: szekanecz.zoltan@med.unideb.hu)

A cikk a Creative Commons Attribution 4.0 International License (https://creativecommons.org/licenses/by/4.0/) feltételei szerint publikált Open Access közlemény, melynek szellemében a cikk bármilyen médiumban szabadon felhasználható, megosztható és újraközölhető, feltéve, hogy az eredeti szerző és a közlés helye, illetve a CC License linkje és az esetlegesen végrehajtott módosítások feltüntetésre kerülnek. (SID_1) 